\title{
Diet of Leptodactylus fuscus (Amphibia: Anura: Leptodactylidae) in the Pantanal of Miranda river, Brazil
}

\author{
José Luiz Massao Moreira Sugai, ${ }^{1,3}$, Juliana de Souza Terra ${ }^{1}$ \& Vanda Lúcia Ferreira ${ }^{1,2}$ \\ ${ }^{1}$ Pós-graduação em Ecologia e Conservação, Universidade Federal de Mato Grosso do Sul - UFMS, \\ Cidade Universitária, CP 549, CEP 79070-900, Campo Grande, MS, Brasil \\ ${ }^{2}$ Centro de Ciências Biológicas e da Saúde, Universidade Federal de Mato Grosso do Sul - UFMS, \\ Cidade Universitária, CP 549, CEP 79070-900, Campo Grande, MS, Brasil \\ ${ }^{3}$ Corresponding author: José Luiz, Massao Moreira Sugai, e-mail: jlmassao@gmail.com
}

SUGAI, J.L.M.M., TERRA, J.S. \& FERREIRA, V.L. Diet of Leptodactylus fuscus (Amphibia: Anura: Leptodactylidae) in the Pantanal of Miranda river, Brazil. Biota Neotrop. 12(1): http://www.biotaneotropica. org.br/v12n1/en/abstract?inventory+bn00812012012

Abstract: Amphibians are usually generalist predators, and their diet is influenced by extrinsic (e.g. food availability) and intrinsic factors (e.g. body size and skull shape). This study aims to describe the diet of adult males and females of Leptodactylus fuscus in the Pantanal of the Miranda river and to answer the following questions: i) Are prey's maximum size and number of food items explained by the anuran's body size? ii) Are richness of morphospecies and number of food items explained by frog sex? iii) Is there diet overlap between male and female? We recorded 62 food items, belonging to seven orders of Arthropoda, and one individual of Annelida. The diet of L. fuscus was dominated by Orthoptera, followed by Coleoptera, Araneae, Hymenoptera, Blattaria, Hemiptera and Diptera. Frog's body size did not influence prey size or number of food items consumed. The number of prey and richness of morphospecies did not differ between males and females. There was low diet overlap between the sexes. Our results provide evidence for the opportunistic and generalist feeding behavior of L. fuscus.

Keywords: Pantanal floodplain, food items, trophic ecology.

SUGAI, J.L.M.M., TERRA, J.S. \& FERREIRA, V.L. Dieta de Leptodactylus fuscus (Amphibia: Anura: Leptodactylidae) no Pantanal do rio Miranda, Brasil. Biota Neotrop. 12(1): http://www.biotaneotropica.org. br/v12n1/pt/abstract?inventory+bn00812012012

Resumo: Anfíbios são, em geral, predadores generalistas cuja dieta é influenciada por fatores extrínsecos (e.g. disponibilidade de alimento) e intrínsecos (e.g. tamanho do corpo e formato do crânio). Este estudo tem como objetivo descrever a dieta de machos e fêmeas adultos de Leptodactylus fuscus no Pantanal do rio Miranda e responder as seguintes perguntas: i) O tamanho máximo da presa e o número de itens alimentares são explicados pelo tamanho corpóreo do anuro? ii) A riqueza de morfoespécies e número de itens alimentares são explicados pelo sexo do anuro? iii) Existe sobreposição de dieta entre macho e fêmea? Registramos 62 itens alimentares distribuídos por sete ordens de Arthropoda e um indivíduo de Annelida. A dieta de L. fuscus possui dominância de Orthoptera, seguida por Coleoptera, Araneae, Hymenoptera, Blattaria, Hemiptera e Diptera. O tamanho corpóreo do anuro não influenciou o tamanho da presa ou o número de itens alimentares consumidos. O número de presas e riqueza de morfotipos não diferiu entre machos e fêmeas. Houve baixa sobreposição alimentar entre os sexos. Os resultados mostram evidências de comportamento alimentar oportunístico e generalista para L. fuscus.

Palavras-chave: planície pantaneira, itens alimentares, ecologia trófica. 


\section{Introduction}

Most amphibians are generalist predators and feed on invertebrates (Rodrigues et al. 2004, Solé et al. 2009, López et al. 2009), but some groups (e.g. Dendrobatidae) are specialized in certain type of prey (Biavati et al. 2004, Wells 2007). In addition, there are species that feed on small vertebrates (Duellman \& Lizana 1994, Sanabria et al. 2005) or even on plant material (Silva et al. 1989, Das 1996). Amphibians occupy an important trophic position in terrestrial and aquatic ecosystems by controlling populations of many organisms, especially invertebrates, and also serving as prey for many organisms (Toledo et al. 2007, Wells 2007). As ectotherms, they don't generate heat metabolically and spend little amount of energy when comparing to endotherms: about $50 \%$ of the energy consumed by amphibians is converted into growth and reproduction (about 2\% in endotherms), which is transferred to the next level of the food chain (Crump 2010).

Generally, the diet of anurans is influenced by morphological traits, such as body size or skull shape (Emerson 1985, Biavati et al. 2004), physiological factors, such as energy demand (Grayson et al. 2005), and by the availability of food resources in the environment (Das 1996, Hirai \& Matsui 2000, Hirai 2004, Lopez et al. 2007, 2009). Several studies show that the predator size explains the variations in abundance and volume of prey, concluding that larger individuals are expected to feed on larger preys and in larger quantity (Maneyro et al. 2004, Biavatti et al. 2004, Sanabria et al. 2005, López et al. 2007). In general, this effect is related to ontogenetic differences in morphology, physiology and behavior (Lima 1998, Lima \& Magnusson 2000, Solé \& Rödder 2010). Another important factor in the diet of frogs is energy demand, which may vary between seasons or sexes (Ryan 1988, Wells 2007). Individuals with higher energetic demands tend to feed in larger quantities (number of prey or volume), which may reflect on the composition of food items (Perry \& Pianka 1997, De Carvalho et al. 2008).

The Pantanal is the largest wetland of the planet (approximately $160.000 \mathrm{~km}^{2}$ ), with well-defined dry and wet seasons and floods whose intensity and duration vary each year (Junk \& Cunha 2005). Most publications about anurans in the Pantanal floodplain refer to species list (Strüssmann et al. 2000), diversity (Strüssmann 2011), description of new species (Ávila et al. 2010), reproductive biology and behavior (Prado \& Uetanabaro 2000, Prado et al. 2000, 2002, 2005) and endoparasites (Campião et al. 2009, 2010). There are only two studies that describe the diet of three anurans species: Leptodactylus podicipinus Cope, 1862 (Rodrigues et al. 2004), Hypsiboas raniceps Cope, 1862 and Scinax acuminatus Cope, 1862 (Sabagh et al. 2010).

Leptodactylus fuscus Schneider, 1799 is a medium-sized frog $(42.8 \pm 4.0 \mathrm{~mm}$ in males and $43.6 \pm 4.4 \mathrm{~mm}$ in females) that belongs to the Leptodactylidae family (Heyer 1978). Occurs from Panama to Argentina in several biomes, is typical of open areas and is considered a good colonizer of recently degraded areas (Wynn \& Heyer 2001, Frost 2011). Reproduction occurs throughout the rainy season in the margins of temporary ponds and swamps (Martins 1988, DeCarvalho et al. 2008). Reproductive activities require much energy, which causes rapid consumption of lipid reserves and demand foraging before and during the period of vocalization in order to maintain reproductive activity (Ryan 1988, Wells 2007). In L. fuscus, males build underground nests to where they attract females, actively defend their territory and vocalize during almost all night and for several months in the rainy season besides the production of gametes, while females are in charge of producing eggs (Martins 1988, DeCarvalho et al. 2008, Maragno \& Cechin 2009). We expected that males had greater diversity and quantity of prey in their stomachs in response of the apparently higher energy demand.

Although L. fuscus is relatively well studied, especially in reproductive aspects (Downie 1984, Martins 1988, OliveiraFilho et al. 2005, De-Carvalho et al. 2008, Lucas et al. 2008), its diet is almost unknown along its wide distribution, with only one study in a Cerrado area in central Brazil (De-Carvalho et al. 2008). The aim of this study is to describe the diet composition of L. fuscus in the Miranda sub-region, southeastern Pantanal (Brazil) and to answer the following questions: i) Are prey's maximum size and number of food items explained by the anuran's body size? ii) Are richness of morphospecies, number of food items and diet composition explained by frog sex? iii) Is there diet overlap between male and female?

\section{Material and Methods}

This study was conducted near to Base de Estudos do Pantanal (BEP, $19^{\circ} 34^{\prime} 37^{\prime \prime}$ S and $57^{\circ} 00^{\prime} 42^{\prime \prime} \mathrm{W}$ ) of the Universidade Federal de Mato Grosso do Sul (UFMS), in the Miranda sub-region (sensu Silva \& Abdon 1998), Corumbá, state of Mato Grosso do Sul, Brazil. The climate is Aw type according to Köppen climate classification, with dry winter semester and markedly aestival precipitation (Peel et al. 2007). Rainfall varies between 800 and $1400 \mathrm{~mm} / \mathrm{year}$, of which $80 \%$ occur between November and March (Silva et al. 2000). The study area includes portions of disturbed riparian forests of the Miranda river and "Paratudal", an arboreal savanna formation with predominance of Paratudo tree (Tabebuia aurea (Manso) Benth. \& Hook. f. ex S. Moore).

We collected frogs monthly between September 2007 and February 2008 with pitfall traps (see Campbell \& Christman 1982) and visual encounter surveys (2 hours/man night) (Crump \& Scott 1994). Four Y-shaped pitfall traps were arranged in the riparian forest of Miranda river and four in "Paratudal". The pitfall traps consisted of four $100 \mathrm{~L}$ buckets (one in the center and one in each end, totaling 32 buckets), remained opened during four nights and checked every morning. We performed the visual encounter surveys in temporary ponds and swampy areas near BEP and in flooded parts of riparian forest. We recorded the snout vent length (SVL) with caliper (to nearest $0.01 \mathrm{~mm}$ ) of each individual. The specimen were killed with an overdose of anesthetic and fixed in $10 \%$ formalin. We analyzed the stomach content under a stereomicroscope, identified each item to the order or family level and assigned to a morphospecies. We divided the morphospecies based on the size and shape of the body, patterns of coloration and characteristics of structures such as wings, legs or mouthparts. After measurement of length and width for each prey, we estimated their volumes using the formula of the ellipsoid: $\mathrm{V}=4 / 3 \pi^{*} 2(\mathrm{~W} / 2)^{2} * \mathrm{~L} / 2$ (where, $\mathrm{V}=$ volume, $\mathrm{W}=$ width, and $\mathrm{L}=$ length) (Magnusson et al. 2003). Partially digested preys were compared to well preserved individuals of the same morphospecies for the estimation of length and width. Specimens were deposited at the Zoological Collection, Section of Herpetology, Universidade Federal de Mato Grosso do Sul at Corumbá (CEUCH).

To verify if larger frogs feed on larger prey and/or in greater quantity we performed two simple linear regression analysis: i) frog's SVL and greater prey volume at a given stomach and, ii) frog's SVL and total number of preys in the stomach. The data meet the statistical assumptions of linearity, normality and homoscedasticity required for linear regression.

To assess the contribution of each morphospecies in the diet of L. fuscus we used the Index of Relative Importance (IRI) through the formula: $I R I=P O *(P N+P V)$, according to Pinkas et al. (1971). PO represents the percentage of occurrence $(100 \times$ number of stomachs containing a certain morphospecies/total number of stomachs), 
PN the numerical percentage $(100 \times$ number of prey of a certain morphospecies in all stomachs/total number of prey in all stomachs) and PV the volumetric percentage $(100 \times$ total volume of certain morphospecies in all stomachs/volume of all prey in all stomachs). To obtain the values of the IRI and the parameters needed for its calculation for each sex, we considered the abundance of each Order as the sum of the number of each morphospecies.

The diet overlap between the sexes was evaluated according to Schoener's index (1970): $\alpha=1-0.5$ ( $\Sigma \mid$ Pxi - Pyi $\mid)$, in which $\alpha=$ diet overlap; Pxi = proportion of food item $I$ found in females; Pyi $=$ proportion of food item $i$ found in males. This index ranges from 0 (no diet overlap) to 1 (complete diet overlap ) (Wallace \& Ramsey 1983). To assess the pattern of occurrence and abundance of food types between sexes, a plot representing the direct ordination of the morphospecies was constructed based on a matrix (lines are the sampling units and columns are abundance of morphospecies), in which the morphospecies are sorted in relation to the weighted average abundance, which is calculated based on the values assigned to each sex ( 0 for females and 1 for males). To test the hypothesis that the richness of morphospecies and the number of prey differs between sexes we used the nonparametric Kruskal-Wallis test (Kruskal \& Wallis 1952). The alpha level used in the tests was 5\%. All the analyses were performed using the software R version 2.12.0 (R Development Core Team 2010).

\section{Results}

From a total of 44 stomachs, eleven (25\%) were empty, and 33 $(75 \%)$ had at least one prey. Of these, 30 were collected by active search and only three by pitfall traps. 18 belonged to males and 15 to females. We found a total of 62 food items belonging to two phyla: Annelida and Arthropoda. We recorded seven orders of Arthropoda, (Araneae, Blattaria, Coleoptera, Diptera, Hemiptera, Hymenoptera and Orthoptera). We also found 16 different morphospecies (Table 1). Frogs ranged in size from 34.97 to $51.09 \mathrm{~mm}$ (41.48 $\mathrm{mm} \pm 3.16)$. The average size of females was slightly larger than males, but there was a great overlap in the amplitude of size (Female: $42.18 \mathrm{~mm} \pm 4.68$; Male: $40.86 \mathrm{~mm} \pm 2.03)$. Neither the maximum volume $\left(r^{2}=0.05\right.$; $\left.\mathrm{F}_{(1,31)}=1.737 ; \mathrm{P}=0.19\right)$, nor the number of food items $\left(\mathrm{r}^{2}=0.01\right.$; $\left.\mathrm{F}_{(1,31)}=0.329 ; \mathrm{P}=0.57\right)$ were explained by frog size.

The IRI was higher in Orthoptera $1($ IRI $=6966.55)$ and lower Diptera (IRI = 4.97) (Table 1$)$. We did not calculate the IRI of Blattaria 2 and Hymenoptera 1 because they were found in advanced degree of digestion. The most important item to both sexes was Orthoptera (IRI = 10355.2 for females and IRI = 6945.01 for males; Table 2) followed by Coleoptera (IRI $=655.01$ for females and IRI $=3986.2$ for males; Table 2).

The Schoener's index indicates low diet overlap between males and females $(\alpha=0.46)$. From the 16 morphospecies found, five $(31.25 \%)$ occurred in both sexes (Coleoptera 1, Coleoptera Staphylinidae, Coleoptera 4, Orthoptera 1 e Orthoptera 2; Figure 1). Three morphospecies $(18.75 \%)$ occurred only in females (Coleoptera 3, Hymenoptera 1 and Hymenoptera 2), while eight (50\%) occurred only in males (Annelida, Araneae, Blattaria 1, Blattaria 2, Diptera, Coleoptera 2, Hemiptera Cicadellidae and Hemiptera 2; Figure 1). The frog's sex did not explain the variations in richness of morphospecies (Kruskal Wallis chi-squared $=0.87 ; \mathrm{p}=0.35$ ) or in the number of prey (Kruskal Wallis chi-squared $=1.30 ; \mathrm{p}=0.25$ ).

\section{Discussion}

The diet composition of anuran can reflect the feeding strategy used by certainly species, which occurs in a continuum between two types: sit-and-wait foragers consume few food items that are large and mobile, while opportunistic searchers consume smaller food items in larger quantities (Solé \& Rödder 2010). The high importance of agile arthropods such as beetles, crickets, grasshoppers, ants and spiders in the diet of species of the Leptodactylus genus indicate more sit-and-wait feeding strategy (Maneyro et al. 2004, Rodrigues et al. 2004, Sanabria et al. 2005, De-Carvalho et al. 2008, Solé et al. 2009). However, in some of these studies there is great quantity of larvae or more sedentary groups, which suggest an opportunistic feeding

Table 1. Morphospecies consumed by Leptodactylus fuscus $(\mathrm{n}=33)$ in the Pantanal of Miranda river, Brazil.

\begin{tabular}{|c|c|c|c|c|c|c|c|}
\hline Food items (morphospecies) & $\mathbf{N}$ & $\% \mathbf{N}$ & $\mathbf{O}$ & $\% \mathbf{O}$ & $\mathbf{V}$ & $\% \mathrm{~V}$ & IRI \\
\hline Phylum Annelida & 1 & 1.61 & 1 & 3.03 & 50.16 & 1.00 & 7.91 \\
\hline \multicolumn{8}{|l|}{ Phylum Arthropoda } \\
\hline Araneae & 3 & 4.84 & 3 & 9.09 & 33.69 & 0.67 & 50.09 \\
\hline Blattaria 1 & 1 & 1.61 & 1 & 3.03 & 169.81 & 3.37 & 15.09 \\
\hline Blattaria 2 & 1 & 1.61 & 1 & 3.03 & - & - & - \\
\hline Diptera & 1 & 1.61 & 1 & 3.03 & 1.57 & 0.03 & 4.97 \\
\hline Coleoptera 1 & 9 & 14.52 & 8 & 24.24 & 403.94 & 8.02 & 546.37 \\
\hline Coleoptera 2 & 2 & 3.23 & 2 & 6.06 & 127.45 & 2.53 & 34.91 \\
\hline Coleoptera 3 & 1 & 1.61 & 1 & 3.03 & 32.92 & 0.65 & 6.85 \\
\hline Coleoptera 4 & 2 & 3.23 & 2 & 6.06 & 64.79 & 1.29 & 27.39 \\
\hline Coleoptera Staphylinidae & 7 & 11.29 & 3 & 9.09 & 45.27 & 0.90 & 110.81 \\
\hline Orthoptera 1 & 27 & 43.55 & 19 & 57.57 & 3903.04 & 77.46 & 6966.55 \\
\hline Orthoptera 2 & 2 & 3.23 & 2 & 6.06 & 148.56 & 2.95 & 37.45 \\
\hline Hemiptera Cicadelidae & 1 & 1.61 & 1 & 3.03 & 8.36 & 0.17 & 5,39 \\
\hline Hemiptera 2 & 1 & 1.61 & 1 & 3.03 & 5.27 & 0.10 & 5,18 \\
\hline Hymenoptera 1 & 1 & 1.61 & 1 & 3.03 & - & - & - \\
\hline Hymenoptera 2 & 2 & 3.23 & 2 & 6.06 & 44.05 & 0.86 & 24.79 \\
\hline Total & 62 & - & - & - & 5038.88 & - & - \\
\hline
\end{tabular}

$\mathrm{N}=$ number of individuals, $\% \mathrm{~N}=$ numeric percentage, $\mathrm{O}=$ occurrence, $\% \mathrm{O}=$ occurrence percentage, $\mathrm{V}=$ total volume of each morphospecies,

$\% \mathrm{~V}=$ volumetric percentage e IRI = index of relative importance. 
Sugai, J.L.M.M. et al.

Table 2. Orders consumed by males and females of Leptodactylus fuscus in the Pantanal of Miranda river, Brazil.

\begin{tabular}{|c|c|c|c|c|c|c|c|}
\hline \multicolumn{8}{|c|}{ Males } \\
\hline Order & $\mathbf{N}$ & $\% \mathrm{~N}$ & $\mathbf{O}$ & $\% 0$ & $\mathbf{V}$ & $\% \mathrm{~V}$ & IRI \\
\hline Anelida & 1 & 2.5 & 1 & 5.55 & 50.16 & 2.02 & 25.09 \\
\hline Araneae & 3 & 7.5 & 3 & 16.67 & 33.69 & 1.35 & 147.53 \\
\hline Blattaria & 2 & 5 & 1 & 5.55 & 169.81 & 6.83 & 65.65 \\
\hline Coleoptera & 16 & 40 & 11 & 61.11 & 627.41 & 25.23 & 3986.2 \\
\hline Hemiptera & 1 & 2.5 & 1 & 5.55 & 8.36 & 0.34 & 15.76 \\
\hline Diptera & 1 & 2.5 & 1 & 5.55 & 1.57 & 0.06 & 14.21 \\
\hline Orthoptera & 16 & 40 & 12 & 66.67 & 1595.47 & 64.17 & 6945.01 \\
\hline Total & 40 & - & - & - & 2486.47 & - & - \\
\hline & \multicolumn{7}{|c|}{ Females } \\
\hline Order & $\mathbf{N}$ & $\% \mathbf{N}$ & $\mathbf{O}$ & $\% 0$ & $\mathbf{V}$ & $\% \mathrm{~V}$ & IRI \\
\hline Coleoptera & 5 & 22.72 & 4 & 26.67 & 46.96 & 1.84 & 655.01 \\
\hline Orthoptera & 13 & 59.1 & 10 & 66.67 & 2456.13 & 96.22 & 10355.2 \\
\hline Hemiptera & 1 & 4.54 & 1 & 6.67 & 5.27 & 0.21 & 31.68 \\
\hline Hymenoptera & 3 & 13.64 & 2 & 13.33 & 44.05 & 1.72 & 204.75 \\
\hline Total & 22 & - & - & - & 2552.41 & - & - \\
\hline
\end{tabular}

$\mathrm{N}=$ number of individuals, $\% \mathrm{~N}=$ numeric percentage, $\mathrm{O}=$ occurrence, $\% \mathrm{O}=$ occurrence percentage, $\mathrm{V}=$ total volume of each morphospecies, $\% \mathrm{~V}=$ volumetric percentage and IRI $=$ index of relative importance.

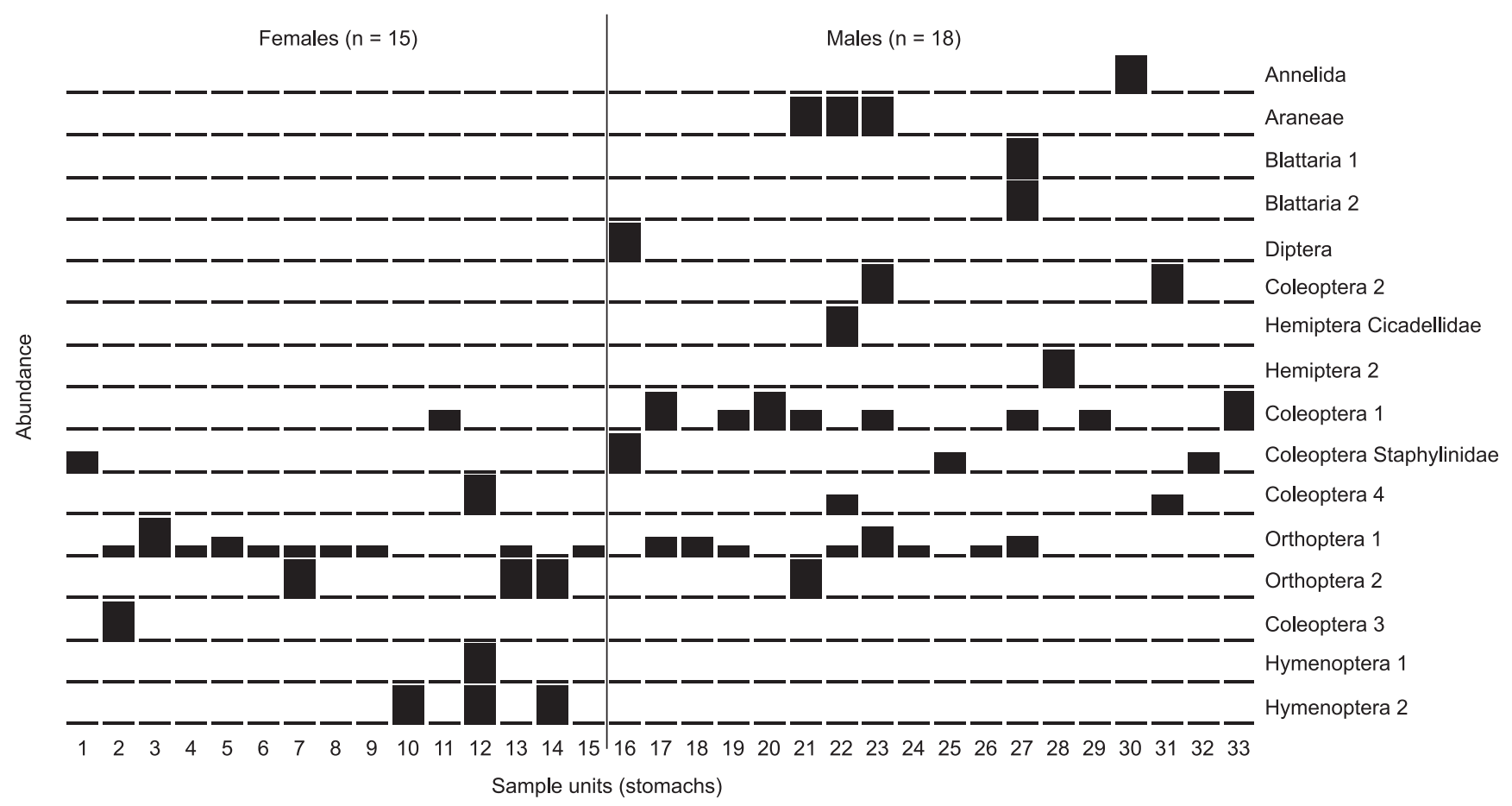

Figure 1. Direct ordination of the 16 morphospecies found in the stomachs of Leptodactylus fuscus in relation to the predator sex. Each set of vertically aligned bar represents a sample unit (33 in total).

behavior in species of the Leptodactylus genus (Solé et al. 2009, Solé \& Rödder 2010). De Carvalho et al. (2008) studied the diet of L. fuscus in a Cerrado area in Goiás state, Brazil, and concluded that Coleoptera was the most important order to the diet of this species, followed by Hymenoptera and Isoptera. The difference in the most important orders in the diet of L. fuscus found in this study and De-Carvalho et al. (2008) can be attributed to opportunistic behavior and differences in prey availability, so that the diet composition is determined by the food availability of arthropods in environments occupied by the population (Das 1996, Hirai \& Matsui 2000, Hirai 2004, Lopez et al. 2007, 2009).

Several studies found a relationship between predator and prey size or prey number, based on stomach contents (Maneyro et al. 2004, Biavatti et al. 2004, Sanabria et al. 2005, López et al. 2007). In general this relationship is attributed to the fact that larger frogs have larger heads and therefore can eat larger prey, which is evident when assessing the diet of young and adult individuals (Solé \& Rödder 2010). This ontogenetic change in prey size is also associated with 
changes in diet composition, since the average size of individuals differs between Arthropoda taxa and the feeding behavior and habitat used by the anuran can change during ontogeny (Simon \& Toft 1991, Solé \& Rödder 2010). The lack of relationship between the frog's size and maximum volume of prey, and frog's size and number of prey obtained in this study may be attributed to the fact that only adults were sampled.

Studies on the diet of L. latrans in Uruguay and western Argentina found great diet overlap between males and females (Maneyro et al. 2004, Sanabria et al. 2005). However, in the study of the Uruguayan population, the authors found differences in the proportion of food items between sexes when considered only individuals collected in the dry season, which was interpreted as adaptations related to the decrease in abundance of prey during this period (Maneyro et al. 2004). In the sampled area, males and females of L. fuscus were collected at the same habitat (margin of water bodies and flooded areas), where probably Orthoptera and Coleoptera were the most abundant Arthropoda order in the sampling period. Nevertheless, the diet overlap was low because of several morphospecies unique to each sex (Figure 1), which appear in only one frog and represented by one prey. The Schoener's index is based on the proportion each food item in each sex and not in the number individuals by food items in each sex, and if the number of sampling units by sex is low diet overlap is probably underestimated because of these uncommon items (Wallace \& Ramsey 1983, Zaret \& Smith 1984). The fact that the morphospecies unique to male of female appeared in only one frog and was represented by one individual indicates that its probably result of chance, since this specie have a generalist feeding behavior.

We conclude that the diet of adult males and females of $L$. fuscus in the Pantanal of Miranda is mainly composed of Orthoptera and Coleoptera, which were probably the most abundant arthropods in the study area during the sampling period. There is no influence of frog size in the maximum size and number of prey, as this relationship is usually related to ontogenetic differences and only adults were used in this study. There is no difference in the number of prey and the abundance of morphospecies between sexes, which indicates similar energy demand of males and females in the reproductive season. The low diet overlap and differences in diet composition between the sexes may be associated with the generalist habit of $L$. fuscus (De-Carvalho et al. 2008), since many food items occurred in only one stomach and were represented by only one prey. We recommend that future studies addressing the diet of frogs use the largest possible range of size (from juveniles to adults) and assess the availability of potential prey in the environment to allow analysis of dietary preference.

\section{Acknowledgements}

Thanks to Coordination of Base de Estudos do Pantanal (BEP) for logistic support and its staff for their help during the field work. To CNPq (PIBIC-UFMS program) and FUNDECT (proc. 41/100.169/2006) for funding the project and to Professor Dr. Gustavo Graciolli for help identifying the arthropods. Thanks to Instituto Brasileiro do Meio Ambiente e dos Recursos Naturais Renovaveis (IBAMA) and to Instituto Chico Mendes de Conservação da Biodiversidade/Sistema de Autorização e Informação em Biodiversidade (ICMBio/SISBIO), for the permits to colect and transport the specimens (\# 10640).

\section{References}

ÁVILA, R.W., PANSONATO, A. \& STRÜSSMANN, C. 2010. A new species of the Rhinella margaritifera group (Anura: Bufonidae) from Brazilian Pantanal. Zootaxa. 2339:57-68.
BIAVATI, G.M., WIEDERHECKER, H.C. \& COLLI, G.R. 2004. Diet of Epipedobates flavopictus (Anura: Dendrobatidae) in a Neotropical Savanna. J. Herpetol. 38(4):510-518. http://dx.doi.org/10.1670/30-04A

CAMPBELL, H.W. \& CHRISTMAN, S.P. 1982. Field techniques for herpetofaunal community analysis. In Herpetological communities (N.J. Scott Junoir, ed.). Fish Wild. Serv. Wildl., Washington, p.193-200.

CAMPIÃO, K.M., SILVA, R.J. \& FERREIRA, V.L. 2009. Helminth parasites of Leptodactylus podicipinus (Anura: Leptodactylidae) from Southestern Pantanal, State of Mato Grosso do Sul, Brazil. J. Helminthol. 83:345349. PMid:19422730. http://dx.doi.org/10.1017/S0022149X09289358

CAMPIÃO, K.M., SILVA, R.J. \& FERREIRA, V.L. 2010. Helminth component community of the paradoxal frog Pseudis platensis Gallardo, 1961 (Anura: Hylidae) from south-eastern Pantanal, Brazil. Parasitol. Res. 106:747-751. PMid:20094893. http://dx.doi.org/10.1007/ s00436-009-1718-0

CRUMP, M.L. 2010. Amphibian diversity and life history. In Amphibian Ecology and Conservation: A Handbook of Techniques (C.K. Dodd Junior, eds.). Oxford University Press, Oxford, p.3-17.

CRUMP, M.L. \& SCOTT, N.J. 1994. Visual encounter surveys. In Measuring and monitoring biological diversity: Standard methods for amphibians (W.R. Heyer, M.A.Donnelly, R.W. McDiarmid, L.A.C. Hayek \& M.S. Foster, eds.).Smithsonian Institution Press, London, p.84-92.

DAS, I. 1996. Folivory and seasonal changes in diet in Rana hexadactyla (Anura: Ranidae). J. Zool. 238:785-794. http://dx.doi. org/10.1111/j.1469-7998.1996.tb05430.x

DE-CARVALHO, C.B., FREITAS, E.B., FARIA, R.G., BATISTA, R.C., BATISTA, C.C., COELHO, W.A. \& BOCCHIGLIERI, A. 2008. Natural history of Leptodactylus mystacinus and Leptodactylus fuscus(Anura: Leptodactylidae) in the Cerrado of Central Brazil. Biota Neotrop. 8:(3): http://www.biotaneotropica.org.br/v8n3/en/ abstract?article+bn01308032008 ISSN 1676-0603 (último acesso em 28/01/2011).

DOWNIE, J.R. 1984. How Leptodactylus fuscus tadpoles make foam, and why. Copeia 1984:778-780.

DUELLMAN, W.E. \& LIZANA, M. 1994. Biology of a sit-and-wait predator, the leptodactylid frog Ceratophrys cornuta. Herpetologica. 50(1):51-64.

EMERSON, S.B. 1985. Skull shape in frogs - correlations with diet. Herpetologica. 41:177-188.

FROST, D. 2011. Amphibian species of the world: an Online Reference. Version 5.5 (31 January, 2011). http://research.amnh.org/herpetology/ amphibia/index.php (último acesso em 11/05/2011).

GRAYSON, K.L., COOK, L.W., TODD, M.J., PIERCE, D., HOPKINS, W.A., GATTEN JUNIOR, R.E. \& DORCAS, M.E. 2005. Effects of prey type on specific dynamic action, growth, and mass conversion efficiencies in the horned frog, Ceratophryscranwelli. Comp. Biochem. Physiol. 141:298304. http://dx.doi.org/10.1016/j.cbpb.2005.05.052

HEYER, W.R. 1978. Systematics of the fuscus group of the frog genus Leptodactylus (Amphibia, Leptodactylidae). Nat. Hist. Mus. Los Angeles Com. Sci. Bull. 29:1-85.

HIRAI, T. \& MATSUI, M. 2000.Feeding Habits of the Japanese Tree Frog, Hyla japonica, in the Reproductive Season. Zool. Sci. 17(7):977-982. http://dx.doi.org/10.2108/zsj.17.977

HIRAI, T. 2004. Diet composition of the Indian rice frog, Rana limnocharis, in the floodplain of the Kizu River, Japan.Herpetol. J. 14:149-152.

JUNK, W.J. \& CUNHA, C.N. 2005. Pantanal: a large South American wetland at a crossroads. Ecol. Eng. 24(4):391-401. http://dx.doi.org/10.1016/j. ecoleng.2004.11.012

KRUSKAL, W.H. \& WALLIS, W.A. 1952. Use of ranks in one-criterion variance analysis. J. Am. Stat. Assoc. 47:583-621. http://dx.doi. org/10.2307/2280779

LIMA, A. P. 1998. The effects of size on the diets of six sympatric species of postmetamorphic litter anurans in Central Amazonia. J. Herpetol. 32(3):392-399. http://dx.doi.org/10.2307/1565453 
LIMA, A.P. \& MAGNUSSON, W.E. 2000.Does foraging activity change with the ontogeny?An assessment for six sympatric species of postmetamorphic litter anurans in Central Amazonia. J. Herpetol. 34(2):192-200. http:// dx.doi.org/10.2307/1565415

LÓPEZ, J.A., GHIRARDI, R., SCARABOTTI, P.A. \& MEDRANO, M.C. 2007. Feeding ecology of Elachistocleis bicolor in a riparian locality of the middle Paraná River. Herpetol. J. 17:48-53.

LÓPEZ, J.A., SCARABOTTI, P.A., MEDRANO, M.C. \& GHIRARDI, R. 2009. Is the red spotted green frog Hypsiboas punctatus (Anura: Hylidae) selecting its preys? The importance of prey availability. Rev. Biol. Trop. 57(3):847-857. PMid:19928476.

LUCAS, E.M., BRASILEIRO, C.A., OYAMAGUCHI, H.M. \& MARTINS, M. 2008. The reproductive ecology of Leptodactylus fuscus (Anura, Leptodactylidae): new data from natural temporary ponds in the Brazilian Cerrado and a review throughout its distribution. J. Nat. Hist. 42(3536):2305-2320. http://dx.doi.org/10.1080/00222930802254698

MAGNUSSON, W.E., LIMA, P.A., SILVA, W.A. \& ARAÚJO, M.C. 2003. Use of geometric forms to estimate volume of invertebrates in ecological studies of dietary overlap. Copeia. 2003(1):13-19.

MANEYRO, R., NAYA, D.E., ROSA, I., CANAVERO, A. \& CAMARGO, A. 2004. Diet of the South American frog Leptodactylus ocellatus (Anura, Leptodactylidae) in Uruguay. Iheringia Sér. Zool. 94(1):57-61.

MARAGNO, F.P. \& CECHIN, S.Z. 2009. Reproductive biology of Leptodactylus fuscus(Anura, Leptodactylidae) in the subtropical climate, Rio Grande doSul, Brazil. Iheringia, Sér. Zool. 99(3):237-241.

MARTINS, M. 1988. Biologia reprodutiva de Leptodactylus fuscus em Boa Vista, Roraima (Amphibia: Anura). Rev. Bras. Biol. 48:969-977.

OLIVEIRA-FILHO J.C., COSTA H.C.M. \& BRAGA U.M.L. 2005. Egg-laying and foam-beating in Leptodactylus fuscus (Anura, Leptodactylidae). Biota Neotrop. 5(2): http://www.biotaneotropica.org. br/v5n2/pt/abstract?short-communication+bn01305022005. (último acesso em 16/09/2011).

PEEL, M.C., FINLAYSON, B.L. \& MCMAHON, T.A. 2007. Updated world map of the Köppen-Geiger climate classification. Hydrol. Earth Syst. Sci. 11:1633-1644. http://dx.doi.org/10.5194/hess-11-1633-2007

PERRY, G. \& PIANKA, E.R. 1997. Animal foraging: past, present and future. Trends Ecol. Evol. 12:360-364. http://dx.doi.org/10.1016/S01695347(97)01097-5

PINKAS, L., OLIPHANT, M.S. \& IVERSON, Z.L. 1971. Food habits of albacore bluefin, tuna and bonito in California waters. Calif. Dept. Fish and Game.152:1-350.

PRADO, C.P.A. \& UETANABARO, M. 2000.Reproductive biology of Lysapus limellus Cope, 1862 (Anura, Pseudidae) in the Pantanal, Brazil. Zoocriaderos.3:25-30.

PRADO, C.P.A., UETANABARO, M. \& LOPES, F.S. 2000. Reproductive strategies of Leptodactylus chaquensis and L. podicipinus in the Pantanal, Brazil. J. Herpetol. 34:135-139. http://dx.doi.org/10.2307/1565249

PRADO, C.P.A., UETANABARO, M. \& HADDAD, C.F.B. 2002. Description of a new reproductive mode in Leptodactylus (Anura, Leptodactylidae), with a review of the reproductive specialization towards terrestriality in the genus. Copeia. 2002(4): 221-245.

PRADO, C.P.A., UETANABARO, M. \& HADAD, C.F.B. 2005. Breeding activity patterns, reproductive modes, and habitat use by anurans (Amphibia) in a seasonal environment in the Pantanal, Brasil. AmphibiaReptilia. 26:211-221. http://dx.doi.org/10.1163/1568538054253375

R DEVELOPMENT CORE TEAM. 2010. R: A language and environment for statistical computing. R Foundation for Statistical Computing, Vienna, Austria. http://www.R-project.org/
RODRIGUES, D.J., UETANABARO, M. \& PRADO, C.P.A. 2004. Seasonal and ontogenetic variation in diet composition of Leptodactylus podicipinus (Anura, Leptodactylidae) in the southern Pantanal, Brazil. Rev. Esp. Herpetol. 18:19-28.

RYAN, M.J. 1988. Energy, Calling and Selection. Amer. Zool. 28:885-898.

SABAGH, L.T., FERREIRA, V.L. \& ROCHA, C.F.D. 2010. Living together, sometimes feeding in a similar way: the case of the syntopic hylid frogs Hypsiboas raniceps and Scinax acuminatus (Anura: Hylidae) in the Pantanal of Miranda, Mato Grosso do Sul State, Brazil. Braz. J. Biol. 70:955-959. Leptodactylus podicipinus

SANABRIA, E.A., QUIROGA, L.B., ACOSTA, J.C. 2005. Dieta de Leptodactylus ocellatus (Linnaeus, 1758) (Anura: Leptodactylidae) en un humedal del oeste de Argentina. Rev. Peru. Biol. 12:472-477.

SCHOENER, T.W. 1970. Non-synchronous spatial overlap lizards in patchy hábitats. Ecology. 51:408-418.

SILVA, J.S.V. \& ABDON, M.M. 1998. Delimitação do Pantanal brasileiro e suas sub- regiões. Pesq. Agropec. Bras. 33:1703-1711.

SILVA, H.R., BRITTO-PEREIRA, M.C. \& CARAMASCHI, U. 1989. Frugivory and seed dispersal by Hyla truncata, a neotropical tree-frog. Copeia. 1989:781-783.

SILVA, M.P., MAURO, R., MOURÃO, G. \& COUTINHO, M. 2000. Distribuição e quantificação de classes de vegetação do Pantanal através de levantamento aéreo. Rev. Bras. Bot. 23(2):143-152.

SIMON, M.P. \& TOFT, C.A. 1991. Diet specialization in small vertebrates: mite-eating in frogs. Oikos 61:263-278. http://dx.doi.org/10.2307/3545344

SOLÉ, M., DIAS, I.R., RODRIGUES, E.A.S., MARCIANO-JUNIOR, E., BRANCO, S.M.J., CAVALCANTE, K.P. \& RODDER, D. 2009. Diet of Leptodactylus ocellatus (Anura: Leptodactylidae) from a cacao plantation in southern Bahia, Brazil. Herpetol. Notes. 2:9-15.

SOLÉ, M. \& RÖDDER, D. 2010. Dietary assessments of adult amphibians. In Amphibian ecology and conservation: a handbook of techniques (C.K. Dodd Junior, eds.). Oxford, Oxford University Press, p.167-184.

STRÜSSMANN, C., PRADO, C.P.A., UETANABARO, M. \& FERREIRA, V.L. 2000. Amphibians recorded during the AquaRAP survey of localities in the southern Pantanal floodplains e surrounding Cerrado, MS, Brasil. In Rapid assessment program, bulletin of biological assessment. A biological assessment of the aquatic ecosystems of the Pantanal, Mato Grosso do Sul, Brasil (P. Willink, B. Chernoff, L. E. Alonso, J.R. Montambault \& R. Lourival, eds.). Conservation International, Washington, p.98-102.

STRÜSSMANN, C., PRADO, C.P.A., FERREIRA, V.L. \& KAWASHITA RIBEIRO, R. 2011. Diversity, ecology, management and conservation of amphibians and reptiles of the Brazilian Pantanal: a review. In The Pantanal: ecology, biodiversity ad sustainable management of a large neotropical seasonal wetland (W.J. Junk, C.J. Da Silva \& K.M. Wantzen, eds.). Pensoft Publishers. Sofia-Moscow. p.497-521.

TOLEDO, L.F., RIBEIRO, R.S. \& HADDAD, C.F.B. 2007. Anurans as prey: an exploratory analysis and the size relationships between predators and their preys. J. Zool. 271:170-177. http://dx.doi.org/10.1111/j.14697998.2006.00195.x

WALLACE, R.K. \& RAMSEY, J.S. 1983.Reliability in measuring diet overlap. Can. J. Fish. Aquat. Sci. 40:347-351. http://dx.doi.org/10.1139/f83-050

WELLS, K.D. 2007.The ecology and behavior of amphibians. University Chicago Press, Chicago, 1148p.

WYNN, A. \& HEYER, W.R. 2001. Do geographically widespread species of tropical amphibians exist? An estimate of genetic relatedness within the neotropical frog Leptodactylus fuscus (Anura, Leptodactylidae). Trop. Zool. 14:255-285.

ZARET, T.M. \& SMITH, E.P. 1984. On measuring niches and not measuring them. In Evolutionary ecology of neotropical freshwater fishes (T.M Zaret Ed.). Dr. W. Junk Publisher, The Hague, p.127-137. 